\title{
The L2 motivational self system, L2 interest, and L2 anxiety: A study of motivation and gender differences in the Croatian context
}

\author{
Anna Martinović \& Izabela Sorić \\ University of Zadar, Croatia
}

\begin{abstract}
Studies have shown that second language (L2) motivation can have an impact on L2 learning processes. The aim of this study was to investigate gender differences in L2 motivation among Croatian university students from the perspective of the L2MSS. The results indicated that females were more motivated than males to learn English, had higher levels of interest in English, while differences in L2 anxiety were somewhat ambiguous. Females also demonstrated that their L2 motivation was linked to motives related to the avoidance of negative outcomes suggesting that females are perhaps more conscientious learners compared to males. These findings point to a complex motivational state among females, which may indicate important gender-based differences in language learning.
\end{abstract}

Key words: L2MSS; L2 interest; L2 anxiety; gender differences.

\section{Introduction}

An abundance of research has been carried out in the field of second language (L2) motivation. Results have indicated the importance of L2 motivation in the second language learning process (Dörnyei, 2005). Gardner's $(1985,2010)$ socio-educational model has long had a major influence in L2 motivation research. In response to increasing discontent with this model, especially in its application in foreign language learning contexts, Dörnyei $(2005,2009)$ introduced the L2 Motivational Self System (L2MSS) which is founded on the concept of future self-guides and the situational context of language learning. Numerous studies have been conducted in various contexts using the L2MSS as a theoretical model to help explain L2 motivation. Nonetheless, it has been shown that cross-culture differences may affect 
motivation with learners from various ethnic groups displaying different values and social norms (Salili et al., 2001; Graham \& Hudley, 2007). Moreover, recent studies have shown that L2 motivation can be affected by gender differences (Henry \& Cliffordson, 2013; You \& Dörnyei, 2014) which suggests an interesting avenue to explore in a specific social context. Although much research has been carried out on L2 motivation in the Croatian context from the social psychological perspective (Mihaljević Djigunović, 1998, Mihaljević Djigunović \& Bagarić, 2007; Pavičić Takač \& Berka, 2014), more research is needed using the L2MSS framework. Dörnyei (Dörnyei, 2005; Dörnyei \& Ottó, 1998), who considered L2 motivation as a long-term process that involves three phases, including the pre-actional, actional, and postactional phase, suggested that elements of the L2MSS can be regarded as motivational influences in the pre-actional phase of L2 motivation along with interest in English and L2 anxiety.

This paper, which is part of a larger study (Martinović, 2014), is concerned with investigating these elements of L2 motivation among Croatian English language learners entering a new phase in their language learning studies. Firstly, a brief literature review of the major concepts is provided. Considering the fact that many studies have found higher L2 motivation among females, in particular, a stronger ideal L2 self, a major aim of the study was to examine gender differences in English L2 motivation with regard to components of the L2MSS. In addition, since studies have shown gender differences in levels of L2 anxiety, as well as lower L2 grades among learners with higher L2 anxiety, this study attempted to test whether proficiency levels based on final English language grades could affect differences and similarities in L2 motivation among females and males. The results of the research are presented concurrently with the discussion where comparisons with other studies are considered and possible explanations for differences are provided.

\section{Theoretical background}

\subsection{The L2MSS}

The L2MSS is a new approach to L2 motivation research based on a 'self' framework, and includes the concept of possible selves which act as future self-guides (Markus \& Nurius, 1986), as well as self-discrepancy theory (Higgins, 1987, 1996, 1998). Dörnyei and Ushioda (2011) argued that future self-guides can be considered a motivational conglomerate that contain the primary organising principles of a complex dynamic system implying the importance of the L2MSS in L2 motivation research. According to Dörnyei (2005), the L2MSS consists of three parts: Ideal L2 Self, Ought-to L2 Self, and 
L2 Learning Experience. Ideal L2 self can be characterised as an individual's image of oneself as a proficient L2 speaker whereby motivation results from the desire to reduce the gap between one's actual and ideal self. The oughtto L2 self is composed of beliefs one has about meeting the expectations of others and preventing possible negative outcomes; that is, motivation deriving from a sense of duty, varied obligations, or responsibilities. The third element of the LSMSS includes L2 learning experience, and consists of motives related to the influence of classroom experiences, which may involve the teacher, curriculum, learner group, or experience of success in the classroom. The interaction of these three components is presumed to have an influence on students' effort to invest in L2 learning. Dörnyei (2005) further suggested that instrumental motives; that is, instrumentality as a concept which considers the utilitarian value of language learning, is an important element in English language learning motivation.

From the self perspective, Csizér and Dörnyei (2005) suggest that depending on the degree of internalization, instrumentality can be divided into two different types. Thus, instrumental motives that have a promotion focus, such as motives related to increasing job success, are related to the ideal L2 self. On the other hand, motives that have not been internalized, for example, studying in order not to fail a course or to avoid parental disappointment, are related to the ought-to self and have a prevention-focus. As a result, Dörnyei (2005) groups instrumental motivation (motives related to external factors) as either instrumentality-promotion or instrumentalityprevention. Empirical validation of the relationship between the L2 selves and instrumentality-promotion and instrumentality-prevention have indicated the complex nature of these relationships, especially regarding instrumentality-prevention (Huang, 2017).

\subsection{L2 interest}

According to Schunk et al. (2010), interest plays an important role in student learning and achievement. The notion of interest can be characterised as the enjoyment and intentional participation in an activity (Schraw \& Lehman, 2001). Schunk et al. (2010) suggested that although interest is not a type of motivation, it can strongly influence motivation. On the other hand, Dörnyei and Ushioda (2011) proposed that interest has notable cognitive features, such as curiosity and engagement with a specific domain, as well as an affective dimension, including the joy that is associated with the engagement in an activity which makes it a potential motivational conglomerate in current socio-dynamic approaches in L2 motivation research. It is worthy to note that interest in foreign languages has been a part of many early L2 frameworks, including Gardner's socio-educational model (1985, 2010), Tremblay and Gardner's model (1995), and William's and Burden's framework (1997). 
Consequently, interest can be regarded as an important factor in the study of learner L2 motivation.

\subsection{L2 anxiety}

Anxiety is difficult to categorize since it is not clear whether it is an element of motivation, a personality trait, or an emotion (Dörnyei, 2005). Nevertheless, it is considered a complex construct which can affect learning, in particular, L2 learning. Two major categories of anxiety have been distinguished in past research. Firstly, facilitating anxiety in contrast to debilitating anxiety where the former can aid performance and the latter can negatively affect performance. Secondly, trait anxiety which is related to a stable personality trait of becoming anxious in many different situations, as opposed to state anxiety which refers to a temporary emotional reaction to a given situation. However, Horwitz et al. (1986) developed a particular concept of anxiety; namely, 'foreign language anxiety' which they argued is situation-specific and may account for low levels of L2 performance. They developed the Foreign Language Classroom Anxiety Scale (FLCAS) which included the following factors: 1) communication apprehension, 2) test anxiety, and 3) fear of negative evaluation. Research has confirmed that language anxiety, as a situation-specific construct, negatively affects L2 performance (MacIntyre, 1999; Oxford 1999; Horwitz, 2001).

In many studies carried out by MacIntyre and his colleagues (MacIntyre, 1999; MacIntyre et al., 2001; MacIntyre et al., 2002), language anxiety was shown to be a specific form of anxiety which is different from general types of anxiety. Earlier studies also showed that experiences in the language learning environment are responsible for the development of language anxiety. Clément's $(1980,1986)$ concept of L2 self-confidence suggested a complex relationship between language anxiety, self-perceptions of L2 proficiency, and motivational factors. Moreover, MacIntyre et al. (1997) suggested that higher levels of anxiety could negatively affect an individual's perception of competence. Briefly, L2 anxiety has been recognized by L2 researchers as an important factor which could influence the L2 learning process and has been in integral part of many L2 motivation frameworks (Dörnyei, 1994; Gardner, 1985, 2010; Tremblay \& Gardner, 1995).

Recent studies have considered the association between L2 anxiety and learner personality which showed a complex relationship between these factors (Dewaele, 2002, Dewaele et al, 2008; Gregersen \& Horwitz, 2002; MacIntyre \& Doucette, 2010). Papi (2010) revealed that a relationship exists between elements of the L2MSS, including the ought-to L2 self among Iranian English language learners. MacIntyre and Serroul (2015) showed that L2 anxiety is the result of numerous dynamically changing processes that take 
place during L2 communication. Several studies have been carried out focusing on L2 anxiety and L2 learning in the Croatian context (Mihaljević Djigunović, 2000, 2002, 2004, 2006; Mihaljević Djigunović \& Legac, 2008). For example, Mihaljević Djigunović (2000) found that females showed higher levels of language anxiety compared to males. Moreover, lower levels of L2 success/grades among high school pupils learning English were found among students with higher levels of L2 anxiety. Furthermore, learners with low self-concept and low motivation also showed higher levels of language anxiety.

\subsection{Second language motivation research and gender differences}

The results of several L2 motivation studies have shown females to be more motivated to learn English (Dörnyei \& Clément, 2001; Dörnyei et al., 2006). Gender differences and L2 motivation research, particularly within the L2MSS framework, has increased in the last few years showing varying results in different contexts. Research focusing on L2 motivation based on the L2MSS framework and gender differences has been carried out in several contexts, including China (You \& Dörnyei, 2014; You et al., 2016), Hungary (Dörnyei \& Clément, 2001; Dörnyei et al., 2006;), Iran (Azarnoosh \& Birjandi, 2012), Japan (Ryan, 2009), Korea (Kim, Yoon-Kyoung, \& Kim, Tae-Young, 2011), and Sweden (Henry \& Cliffordson, 2013) to name only a few. The results of these studies are not quite consistent. For example, Ryan (2009) found that females showed significantly higher scores on the ideal L2 selfvariable among Japanese learners of English, while Azarnoosh and Birjandi's (2012) study focusing on junior high school students found that females showed significantly higher values on the ideal L2 self, but also on the ought-to L2 self- variables. Henry (2009) found that girls' ideal L2 selves became stronger over a three-year period in Sweden. Henry and Cliffordson's study (2013) revealed stronger ideal L3 self among women, but no gender differences were found for ideal L2 English selves. They suggested that discrepancies in gender can be explained with respect to differences in the way individual selves are created and interpreted with male selves identifying with independence, and female selves with interdependence. Accordingly, they suggest that females' ideal L2 selves are usually stronger than males because they can imagine themselves using the language proficiently in the future with target language speakers. From an educational psychological view, studies have shown that gender differences in L2 motivation are the result of gender differences in self-perceptions of ability, since these differences may be affected by cultural gender-role norms and stereotypes (Eccles et al, 1998).

In a previous paper, Martinović (2017) found a positive relationship between L2 anxiety and gender using a correlation analysis; in addition, mul- 
tiple regression analysis showed gender to be a predictor variable of L2 anxiety. Differences among English L2 university learners were found among different areas of study in another study (Martinović, 2018). A two-way ANCOVA analysis was used to identify whether gender had an effect on differences in motivation among different groups of students with English grades as the control variable. The results showed gender to have a significant effect on the ought-to L2 self-scale with higher levels found among females compared to males if they were biomedical, biotechnical or technical students. Conversely, motivation related to the ought-to L2 self was higher among males compared to females in the humanities and social science fields of studies. In the present study, the same sample is used to confirm differences among gender using other data analyses to further explore these results and to investigate these differences among various motivational factors, in particular, components of the L2MSS.

\section{Aim}

This study is part of a larger unpublished study (Martinović, 2014) which considered L2 motivation among English language learners. The general aim of this paper was to investigate gender differences among the various variables of the L2MSS, including the ideal L2 self, ought-to L2 self, instrumentality-promotion, instrumentality-prevention, as well as L2 interest, L2 anxiety and intended effort on a sample of Croatian university student. In this follow-up study, inferential analyses were undertaken in an attempt to help explain whether proficiency levels might have had an effect on the results.

\subsection{Research questions}

The following research questions were investigated:

1. Are there differences among gender with regard to elements of the L2MSS, L2 interest, and L2 anxiety?

2. Are there differences among gender in L2 motivation variables when controlling for grade levels?

\section{Method}

The following section provides descriptive information concerning the sample. In addition, the type of instrument used in the study is described along with how the study was carried out. Furthermore, the results of the reliability analysis for the questionnaire are presented, as well as the description of the data analysis. 


\subsection{Sample}

The sample originally included 555 first year non-English major students from the University of Zadar; however, twelve questionnaires were not completed and were discarded. Students who completed the questionnaire included 204 males (37.6\% of the total sample) and 339 females $(62.4 \%$ of the total sample).

English is an obligatory school subject in Croatia so students had prior knowledge of English before their enrolment in university. Years of studying English varied from 4 to 16 years with an average mean of 10.3 years $(\mathrm{SD}=$ 2.22). On a scale of 1 to 5 , with 5 being the highest grade, the mean average of students' final English high school grade was $3.7(\mathrm{SD}=0.93)$.

\subsection{Instruments and procedures}

A two-part questionnaire was used to obtain the data. The first part acquainted the students with the study's objectives, provided instructions, and asked for the following background information: gender, field of study, years of studying English, and final English grade in high school. The second part of the questionnaire focused on motivational components of the L2MSS, along with other motivational influences (L2 interest and L2 anxiety), as well as intended effort as the criterion variable. It is comprised of seven 6-point Likert rating scales adapted from Taguchi et al.'s (2009) motivation questionnaire and included all three versions of the original questionnaire (Japanese, Chinese and Iranian). The questionnaire was previously piloted on a Croatian sample (Martinović, 2013) and showed good internal consistency. In this study, factor analyses showed a one-factor structure for all the used scales; moreover, the results of the reliability analyses showed good internal consistency (Cronbach alpha scores - a) among the scales: Intended effort - Criterion measure ( 9 items, $\mathrm{a}=.83$ ), Ideal L2 Self (10 items, $\mathrm{a}=.92)$, Ought-to L2 Self 12 items, $\mathrm{a}=.87$ ), Instrumentality-promotion (13 items, $\mathrm{a}=.82)$, Instrumentality-prevention ( 8 items, $\mathrm{a}=.80)$ Interest in the English language - L2 interest (4 items, $\mathrm{a}=.74)$, L2 anxiety (10 items, .95).

Students were given the questionnaire to fill out during their English class at the start of their first year of university studies. Students were informed of the aims and purpose of the study before they filled out the questionnaire and were told that it was anonymous. A consent form was signed by all the students before they completed the questionnaire.

\subsection{Data analysis}

In order to answer the research questions, several analyses were carried out. Firstly, descriptive analysis was applied to obtain information about the 
sample. Next, a t-test was used to discover differences among gender for the various motivation variables. Secondly, a one-way ANCOVA analysis was used to investigate whether grade levels had an effect on gender differences in L2 motivation.

\section{Results and discussion}

In this section the results of the data analyses are presented. Firstly, the question of gender differences among the motivation variables is addressed. Secondly, differences among males and females in English language learning motivation is considered while controlling for grade levels. A concurrent discussion is given following the results of each analysis and comparisons are made with other studies where applicable.

\subsection{Gender differences}

In order to answer the first research question, a t-test was carried out to discover gender differences among the motivation variables. The results of the independent samples t-test showed no significant differences between males and females for the following L2MSS scales: Ideal L2 Self, Ought-to L2 Self, Instrumentality-promotion (see Table 1). These results are in contrast to many other studies which have investigated the relationship among elements of the L2MSS and gender among L2 learners. For instance, Ryan (2009) found that females showed significantly higher scores on the ideal L2 self -variable in a study among Japanese learners of English, which included non-language university majors, language majors, and secondary school pupils. In their sample of junior high school students in Iran, Azarnoosh and Birjandi (2012) also found gender differences, with females showing significantly higher means on the ideal L2 self and on the ought-to L2 selfvariables. In a study on Korean students, Kim Yoon-Kyoung and Kim TaeYoung (2011) found that female students showed a clearer vision of their ideal L2 self compared to males and were more motivated to learn the L2. In addition, You and Dörnyei (2014) found higher English language learner motivation among females, including a higher average on the ideal L2 selfscale among non-English major university students in the Chinese context. Previous studies on L2 motivation (Dörnyei \& Clément, 2001; Dörnyei et al., 2006) demonstrated higher scores on integrativeness and instrumentality among females. Csizér and Dörnyei (2005: 29) identified integrativessness "as the L2 representation of one's ideal self."

However, the results of this study indicated that both males and females had a comparatively strong ideal L2 self. Furthermore, studying English for instrumental reasons related to their future studies and jobs was important 
for both genders as shown by the results on the instrumentality-promotion variable. Moreover, males and females had comparatively low levels of motivation related to pressure from the people surrounding them, such as their parents, teachers, or peers (ought-to L2 self). Similarly, Henry and Cliffordson (2013) found no gender differences for the ideal L2 English self among Swedish L2 high school learners. The authors suggested that the status of English in Sweden today, along with the fact that the scale they used entailed visions of professional success, may be some of the reasons for this lack of difference. Likewise, it is possible that Croatian students consider knowledge of English as a basic educational tool (Dörnyei \& Ushioda, 2011) and have affiliated it with professional success regardless of gender. Moreover, low levels on the ought-to L2 self-scale could be explained by the fact that extrinsic motivation has become internalized (Dörnyei, 2005) since the sample included older learners, that is, university students who have learned English for an average of 10 years.

Table 1: Differences in the results of Intended effort, the L2MSS, L2 Interest, L2 Anxiety scales, and final English high school grades between males and females - Results of independent samples t-test.

\begin{tabular}{|c|c|c|c|c|c|c|c|}
\hline Scale & Gender & $\mathbf{N}$ & $\mathbf{M}$ & SD & $T$ & df & $\mathbf{p}$ \\
\hline \multirow[t]{3}{*}{ Intended effort } & Male & 199 & 3.36 & 0.92 & & & \\
\hline & Female & 334 & 3.85 & 0.81 & & & \\
\hline & Total & 533 & & & -6.29 & 374 & $.000^{*}$ \\
\hline \multirow[t]{3}{*}{ Ideal L2 Self } & Male & 199 & 4.52 & 0.96 & & & \\
\hline & Female & 330 & 4.42 & 1.03 & & & \\
\hline & Total & 529 & & & 1.14 & 527 & .256 \\
\hline \multirow{3}{*}{$\begin{array}{l}\text { Ought-to L2 } \\
\text { Self }\end{array}$} & Male & 192 & 2.92 & 0.86 & & & \\
\hline & Female & 329 & 2.86 & 0.89 & & & \\
\hline & Total & 521 & & & .678 & 519 & .498 \\
\hline \multirow{3}{*}{$\begin{array}{l}\text { Instrumentality } \\
\text { - promotion }\end{array}$} & Male & 196 & 4.24 & 0.71 & & & \\
\hline & Female & 329 & 4.34 & 0.76 & & & \\
\hline & Total & 525 & & & -1.50 & 523 & .133 \\
\hline \multirow{2}{*}{$\begin{array}{l}\text { Instrumental- } \\
\text { ity - preven- }\end{array}$} & Male & 201 & 3.75 & 0.95 & & & \\
\hline & Female & 333 & 3.95 & 0.96 & & & \\
\hline
\end{tabular}




\begin{tabular}{llllllll}
\hline \multirow{2}{*}{ tion } & Total & 534 & & & -2.37 & 532 & $.018^{*}$ \\
\hline L2 Interest & Male & 198 & 3.78 & 0.98 & & & \\
& Female & 336 & 4.29 & 0.96 & & & \\
& Total & 534 & & & -5.87 & 532 & $.000^{*}$ \\
\hline L2 Anxiety & Male & 198 & 2.49 & 1.14 & & & \\
& Female & 334 & 3.28 & 1.28 & & & \\
& Total & 532 & & & -7.12 & 530 & $.000^{*}$ \\
\hline Final English & Male & 204 & 3.53 & .964 & & & \\
Grades & Female & 339 & 3.80 & .897 & & & \\
& Total & 543 & & & -3.28 & 404 & $.001^{*}$ \\
\hline${ }^{*} \mathrm{p}<.05$ & & & & & & &
\end{tabular}

Nevertheless, differences between males and females were found on several other scales indicating a more complex picture of gender specific language self-concepts. Firstly, the results showed significantly higher average means among females on the instrumentality-prevention scale indicating that females were more extrinsically motivated to learn English compared to males. The instrumentality-prevention scale contained statements focusing on several extrinsic motives, including the importance of acquiring a university degree, being professionally successful, as well as the importance of good grades. For example, the items on the scale encompassed statements such as, "I have to learn English because without passing the English course I cannot graduate"; "I have to study English because I don't want to get bad marks in it at university"; "I have to study English; otherwise, I think I cannot be successful in my future career"; "Studying English is important to me because, if I don't have knowledge of English, I'll be considered a weaker student." Consequently, it may be suggested that females attached importance to external rewards such as acquiring their degrees, getting good grades, being successful in their careers, and obtaining a respectable status in society. In other words, according to the statements by which instrumentality-prevention was operationalised, it may be asserted that females were more turned toward avoiding negative outcomes. This result has interesting implications regarding L2 motivation as will be shown below.

Namely, females also showed significantly higher mean averages on the intended effort and interest scales compared to males. Specifically, females intended to exert more effort in learning English and were more interested in the English language than males at the beginning of the academic year. Essentially, this implies that females were more motivated to learn English compared to males. These results may be explained in relation to the scores 
obtained on the instrumental-prevention scale which showed higher results for females. Research has indicated that a possible self that is offset or balanced by an opposing feared possible self, such as the fear of the negative consequences of not achieving a goal, affects motivation to a greater extent (Carver et al., 1994; Oyserman \& Markus, 1990; Oyserman et al., 2004; Oyserman et al., 2006). Markus and Ruvolo (1989) also argued that a balance between an individual's expected and feared self supports a better motivational state compared to an expected possible self or a feared self alone. Therefore, one possible explanation for higher motivation to learn English among females may be the balance between their ideal L2 self and their fear of negative consequences. There are several implications which can be drawn from these results. Firstly, both males and females had a strong ideal L2 self and regarded English language learning as important for instrumental reasons related to job promotion; nevertheless, it is possible that females were more motivated to learn English because their ideal L2 self was offset by their feared self, implying that this is an important variable in the motivation equation. In addition, the results indicate that the division of instrumentality into two types offers a more comprehensive description of the motivational composition of learners. Lastly, the results of this study basically endorse the results of other L2 motivation studies which revealed higher motivation to learn English among females (Dörnyei \& Clément, 2001; Dörnyei et al., 2006).

Along with differences between genders with regard to the L2MSS variables, dissimilarities were also found in L2 anxiety. It was shown that females had significantly higher mean averages of L2 anxiety in comparison to males. This result is in accordance with other research results in Croatia (Mihaljević Djigunović, 2000) which also revealed higher L2 anxiety levels among females. In this study, the type of items on the anxiety scale were related to L2 language use inside and outside the classroom. Examples of items used on this scale included the following statements: "I get nervous and confused when I am speaking in my English class," "I would feel uneasy speaking English with a native speaker," "I would get tense if a foreigner asked me for directions in English." Based on these statements, it appears that females were more self-conscious, anxious and lacked selfconfidence in the use of English compared to males.

The results showing higher L2 anxiety among females are composed of several contradictory features. Namely, research has shown that language anxiety affects L2 learning (Gardner \& MacIntyre, 1993; MacIntyre et al., 1997; MacIntyre, 1999; Oxford, 1999; Horwitz, 2001;). Moreover, L2 research studies (Mihaljević Djigunović, 2000, 2002) have found that higher levels of language anxiety were related to lower levels of motivation. Nonetheless, the results of this study indicated that although females had higher levels of 
L2 anxiety, they were also more motivated to learn English (see results above). In addition, females had significantly higher final English high school grades than males (see Table 1). Alpert and Haber (1960) have claimed that language anxiety could be considered as debilitative, or harmful anxiety, and facilitative, or helpful anxiety. Various studies (Horwitz, 1990; Young, 1992; Ehrman \& Oxford, 1995) have shown that facilitative anxiety can help in learning a foreign language. Therefore, it is possible that females experienced a 'facilitative' type of anxiety which would not hinder future efforts or success in English language learning.

Alternatively, higher levels of L2 anxiety among females may be explained within the context of Clément's concept of linguistic self-confidence. Clément et al. (1994) defined self-confidence in L2 usage as consisting of a low anxious affect as well as high self-perceptions of L2 competence. Studies (Clément, 1980; Clément et al., 2003; MacIntyre et al., 1997) have indicated that the concepts of anxiety and self-evaluation are closely linked in L2 contexts. Consequently, it is conceivable that females may have had low perceptions of their English language competence which augmented their level of L2 anxiety. Even though females had higher English grades, which suggests higher L2 competence, nonetheless, their perceptions of this L2 competence was low, resulting in an increase in L2 anxiety. MacIntyre (1994) has maintained that Willingness to communicate (WTC) is connected to L2 selfconfidence which may also help to explain L2 anxiety. MacIntyre and his colleagues (1998) found that many students who had high levels of linguistic competence were unwilling to use their L2 for communication. Interestingly, gender differences in self-perceptions of ability have also been found in studies in educational psychology which suggested the influence of cultural gender-role norms and stereotypes (Eccles et al., 1998). Studies have found gender differences in ability perceptions at an early age with girls showing lower ability self-perception than boys, although there were no differences in skill levels (Entwisle \& Baker, 1983; Frey \& Ruble, 1987). In addition, Pajares (2008) considered the possibility that gender differences in self-efficacy are the consequence of the fact that boys are more inclined to express confidence in possessing skills that they may not have and even express excessive confidence in the skills they have. This self-congratulatory bias may simply lead to the fact that girls and boys do not use 'the same measuring stick' when evaluating self-confidence.

\subsection{Gender differences and grade levels}

Studies have found that proficiency levels are an important element of L2 motivation (Gardner, 1985, 2010). Martinović (2018) found that students who had higher English grades also had a stronger ideal L2 self, and motives 
related to instrumentality-promotion; in addition, they intended to exert more effort in their English language learning. The second research question was aimed at understanding the impact of grades in order to obtain a clearer picture of the motivational profile of females and males. A one-way ANCOVA (analysis of covariance) was carried out in order to compare the effect of gender on the L2 motivational variables which showed significant differences between males and females while controlling for grade levels. Specifically, the analyses were conducted on the following scales: Intended effort, Instrumentality-prevention, Interest, and L2 Anxiety.

The results of the one-way ANCOVA indicated that gender had a significant effect on the Intended effort scale, $\mathrm{F}(1,530)=31.803, \mathrm{p}<.001$, even when controlling for grade levels, $\mathrm{F}(1,530)=63.48$, $\mathrm{p}<.001$ ) with the following adjusted means: $M=3.41$ (males), $M=3.82$ (females). With regard to L2 anxiety, the results showed that gender had a significant effect on this scale, $F(1$, $529)=75.35, \mathrm{p}<.001$, while adjusting for grade levels, $\mathrm{F}(1,529)=72.78, \mathrm{p}<.001$, with adjusted mean levels indicating males having lower levels of L2 anxiety $(\mathrm{M}=2.49)$ compared to females $(\mathrm{M}=3.32)$. However, the results of Levene's homogeneity of variance test indicates that equality of variance cannot be assumed $(p<0.05)$ for these scales and so this result cannot be considered valid.

Nevertheless, Levene's test showed equality of variance $(p>0.05)$ on the other two scales. Gender had a significant effect on the Instrumentalityprevention scales, $\mathrm{F}(1,531)=7.721, \mathrm{p}<.005$, whilst adapting for grade levels, $\mathrm{F}(1,531)=8.933, \mathrm{p}<.005$, with adjusted means showing higher levels among females $(M=3.97)$ in contrast to males $(M=3.73)$. In addition, gender had an effect on the Interest scale, $\mathrm{F}(1,531)=26.247$, $\mathrm{p}<.001$, with significance also shown when adjustments were made for grade levels, $F(1,531)=46.723$, $\mathrm{p}<.001$, indicating higher mean levels of interest in English among females $(\mathrm{M}=4.26)$ in comparison with males $(\mathrm{M}=3.83)$.

These results confirm that females were more interested and more motivated in learning English in comparison with males even when controlling for grade levels, as well as more motivated to learn English in order to avoid negative consequences related to their careers. It has been suggested that these findings support the view that females are more motivated to learn English because their ideal L2 self is counterbalanced with a feared self. Differences between males and females regarding L2 anxiety when controlling for grade levels could not be considered. In a survey of gender differences and L2 motivation, Henry and Cliffordson (2013) noted that studies in possible selves research showed that females' possible selves were characterised by qualities of an interpersonal nature and that they adapted themselves to the performance of others. Moreover, according to these authors, research has shown that females' feared selves are also associated more with inter- 
personal relationships which may help explain female concerns with 'doing well,' or sense of obligation which is reflected in the instrumentalityprevention scale. Further clarification of the result referring to the avoidance of negative consequences may be found in studies from educational psychology which have found females to be more conscientious learners compared to males. Most previous research has indicated that, amongst the Big Five personality traits, 'conscientiousness' had the strongest relationship with learning and academic achievement (Noftle \& Robins, 2007; O'Connor \& Paunonen, 2007). Conscientious people are considered to be responsible, well-organized, industrious, reliable, disciplined and dedicated; in addition, conscientious individuals are self-controlled, they follow rules and maintain goal-pursuits. Therefore, the fact that conscientiousness has been related to academic achievement is not unexpected. Some research suggested that women are ranked somewhat higher than men on several specific facets of conscientiousness, such as order, dutifulness, and self-discipline (Weisberg et al., 2011). Accordingly, the findings in this study may indicate that females are more conscientious English language learners than males and that females' self-concept is related to a sense of dutifulness and self-discipline.

\section{Conclusion}

This study focused on gender differences in L2 motivation based on the L2MSS and various other important L2 motivation factors, including L2 interest and L2 anxiety. In contrast to many other studies in different social contexts, the results indicated no gender differences among Croatian L2 learners regarding their ideal L2 self, motivation related to the use of English for professional success (instrumentality-promotion), and pressure from significant others (ought-to L2 self). It has been suggested that young people at university in Croatia recognize the importance of having knowledge of English in today's globalized world regardless of gender. However, the results revealed higher motivation among females, with females showing higher L2 interest and intended effort in learning English at university, but also higher levels of motivation related to the avoidance of negative outcomes (instrumentality-prevention). It was suggested that females had an ideal L2 self that was offset by a feared self, which may have led to a heightened motivational state. In addition, females displayed higher levels of L2 anxiety, regardless of the fact that they had higher high school English grade levels. Possible explanations were given, for example, females may have had a facilitative type of anxiety which encouraged them to try harder, or they had low L2 self-confidence which was affected by their self perceptions of language ability. When the effect of grade levels was taken into consideration, gender differences were still found on the intended effort, interest and 
instrumentality-prevention scales indicating higher L2 motivation among females, while gender differences in L2 anxiety could not be determined. The finding regarding higher levels of motivation related to the avoidance of negative outcomes is particularly interesting. It has been suggested that female possible selves could be more of an 'interpersonal' nature which encourages them to be more attuned to their surroundings and to their relationships with significant others, or simply that females were more conscientious learners compared to males. An interesting factor that emerged from this study is the importance of classifying instrumentality into two distinct categories as the results show gender differences between instrumentalitypromotion and instrumentality-prevention. The results are in compliance with other studies which showed differences among genders in L2 motivation; however, the results of this study show that these differences may be culture specific. Clearly, more qualitative, longitudinal, and cross-cultural research is needed to better explain these differences.

\section{References}

Alpert, Richard, Ralph Norma Haber (1960). Anxiety in academic achievement situations. The Journal of Abnormal and Social Psychology 61(2): 207-215.

Azarnoosh, Maryam, Parviz Birjandi (2012). Junior high school students' L2 motivational self system: Any gender differences? World Applied Sciences Journal 20(4): 577-584.

Carver, Charles S., Sakina L. Reynolds, Michael F. Scheier (1994). The possible selves of optimists and pessimists. Journal of Research in Personality 28: 133-141.

Clément, Richard (1980). Ethnicity, contact and communicative competence in a second language. In Giles, Howard, Peter W. Robinson, Philip M. Smith, eds. Language: Social Psychological Perspectives. Oxford: Pergamon, 147-154.

Clément, Richard (1986). Second language proficiency and acculturation: An investigation of the effects of language status and individual characteristics. Journal of Language and Social Psychology 5: 271-290.

Clément, Richard, Zoltán Dörnyei, Kim A. Noels (1994). Motivation, self-confidence, and group cohesion in the foreign language classroom. Language Learning 44(3): 417-448.

Clément, Richard, Susan C. Baker, Peter D. MacIntyre (2003). Willingness to communicate in a second language: The effects of context, norms, and vitality. Language Learning 44: 417-448.

Csizér, Kata, Zoltán Dörnyei (2005). The internal structure of language learning motivation and its relationship with language choice and learning effort. Modern Language Journal 89(1): 19-36.

Dewaele, Jean-Marc (2002). Psychological and sociodemographic correlates of communicative anxiety in L2 and L3 production. International Journal of Bilingualism 8(1): 23-38.

Dewaele, Jean-Marc, Konstantinos V. Petrides, Adrian Furnham (2008). The effects of trait emotional intelligence and sociobiological variables on communicative 
anxiety and foreign language anxiety among adult multilinguals: A review and empirical investigation. Langauge Learning 58(4): 911-960.

Dörnyei, Zoltán (1994). Motivation and motivating in the foreign language classroom. Modern Language Journal 78(3): 273-284.

Dörnyei, Zoltán, István Ottó (1998). Motivation in action: A process model of L2 motivation. Working Papers in Applied Linguistics (Thames Valley university, London) 4: 43-69.

Dörnyei, Zoltán, Richard Clément (2001). Motivational characteristics of learning different target languages: Results of a nationwide survey. In Dörnyei, Zoltán, Richard Schmidt, eds. Motivation and Second Language Acquisition. Honolulu, HI: University of Hawaii Press, 399-423.

Dörnyei, Zoltán (2005). The Psychology of the Language Learner: Individual Differences in Second Language Acquisition. Mahwah, NJ: Lawrence Erlbaum.

Dörnyei, Zoltán, Kata Csizér, Nóra Németh (2006). Motivation, Language Attitudes and Globalisation: A Hungarian Perspective. Clevedon: Multilingual Matters.

Dörnyei, Zoltán (2009). The L2 motivational self system. In Dörnyei, Zoltán, Ema Ushioda, eds. Motivation, Language Identity and the L2 Self. Bristol: Multilingual Matters, 9-42.

Dörnyei, Zoltán, Ema Ushioda (2011). Teaching and Researching Motivation (2nd ed.). Harlow: Pearson Education.

Eccles, Jacquelynne S., Bonnie Barber, Debbie Jozefowicz (1998). Linking gender to educational, occupational, and recreational choices: applying the Eccles et al. model of achievement-related choices. In Swann, William B., Judith H. Langlois, Lucia Albino Gilbert, eds. Sexism and Stereotypes in Modern Society: The Gender Science of Janet Taylor Spence. Washington, DC: American Psychological Association, 153-192.

Ehrman, Madeline, Rebecca L. Oxford (1995). Cognition plus: Correlates of language proficiency. Modern Language Journal 79: 67-89.

Entwisle, Doris R., David P. Baker (1983). Gender and young children's expectations for performance in arithmetic. Developmental Psychology 19(2): 200-209.

Frey, Karin, Diane N. Ruble (1987). What children say about classroom performance: Sex and grade differences in perceived competence. Child Development 58(4): 1066-1078.

Gardner, Robert C. (1985). Social Psychology and Second Language Learning: The Role of Attitudes and Motivation. London: Edward Arnold.

Gardner, Robert C., Peter D. MacIntyre (1993). On the measurement of affective variables in second language learning. Language Learning 43(2): 157-194.

Gardner, Robert C. (2010). Motivation and Second Language Acquisition: The SocioEducational Model. New York: Peter Lang Publishing Inc.

Gregersen, Tammy, Elaine, K. Horwitz (2002). Language learning and perfectionism: Anxious and non-anxious language learners' reactions to their own oral performance. The Modern Language Journal 86(4): 562-570.

Graham, Sandra, Cynthia Hudley (2007). Race and ethnicity in the study of motivation and competence. In Elliot, Andrew J., Carol S. Dweck, eds. Handbook of Competence and Motivation. New York/London: The Guilford Press, 392-413.

Henry, Alastair (2009). Gender differences in compulsory school pupil's L2 selfconcepts: A longitudinal study. System 37(2): 177-193. 
Henry, Alastair, Christina Cliffordson (2013). Motivation, gender, and possible selves. Language Learning 63(2): 271-295.

Higgins, E. Tory (1987). Self-discrepancy: A theory relating self and affect. Psychological Review 94(3): 319-340.

Higgins, E. Tory (1996). The 'self-digest': Self-knowledge serving self-regulatory functions. Journal of Personality and Social Psychology 71(6): 1062-1083.

Higgins, E. Tory (1998). Promotion and prevention: Regulatory focus as a motivational principle. Advances in Experimental Social Psychology 30: 1-46.

Horwitz, Elaine K., Michael B. Horwitz, Joann Cope (1986). Foreign language classroom anxiety. Modern Language Journal, 70(2): 125-132.

Horwitz, Elaine K. (1990). Attending to the affective domain in the foreign language classroom. In Magnan, Sally S., ed. Shifting the Instructional Focus to the Learner. Middlebury, VT: Northeast Conference on the Teaching of Foreign Languages, 15-33.

Horwitz, Elaine K. (2001). Language anxiety and achievement. Annual Review of Applied Linguistics 21: 112-126.

Huang, Hung-Tzu (2017). Private English tutoring and adolescents' motivation to learn English as a foreign language: A self-system perspective. Taiwan Journal of TESOL 14(1): 1-36.

Kim, Yoon-Kyoung, Tae-Young Kim (2011). Gender differences in Korean secondary school students' learning styles and L2 motivation. Foreign Language Education 18(2): 51-71.

MacIntyre, Peter, D. (1994). Variables underlying willingness to communicate: A causal analysis. Communication Research Reports, 11(2) : 135-142.

MacIntyre, Peter D., Kim A. Noels, Richard Clément (1997). Biases in self-ratings of second language proficiency: The role of language anxiety. Language Learning 47(2): 265-287.

MacIntyre, Peter D., Richard Clément, Zoltán Dörnyei, Kim, A. Noels (1998). Conceptualizing willingness to communicate in a L2: A situated model of confidence and affiliation. Modern Language Journal, 82(4): 545-562.

MacIntyre, Peter D. (1999). Language anxiety: A review of the research for language teachers. In Young, Dolly J., ed. Affect in Foreign Language and Second Language Learning. Boston: McGraw-Hill, 24-45.

MacIntyre, Peter D., Susan C. Baker, Richard Clément, Sarah Conrod (2001). Willingness to communicate, social support, and language learning orientations of immersion students. Studies in Second Language Acquisition 23(3): 369-388.

MacIntyre, Peter D., Susan C. Baker, Richard Clément, Leslie A. Donovan (2002). Sex and age effects on willingness to communicate, anxiety, perceived competence, and L2 motivation among junior high school French immersion students. Language Learning 52: 537-564.

MacIntyre, Peter D., Jesslyn Doucette (2010). Willingness to communicate and action control. System 38(2): 161-171.

MacIntyre, Peter D., Alicia Serroul (2015). Motivation on a per-second timescale: Examining approach-avoidance motivation during L2 task performance. In Dörnyei, Zoltán, Peter, D. MacIntyre, Alastair Henry, eds. Motivational Dynamics in Language Learning, Bristol: Multilingual Matters, 109-138.

Markus, Hazel, Paula Nurius (1986). Possible selves. American Psychologist 41(9): 954969. 
Markus, Hazel, Ann Ruvolo (1989). Possible selves: Personalized representations of goals. In Pervin Lawrence A., ed. Goal Concepts in Personality and Social psychology, Hillsdale, NJ: Erlbaum, 211-241.

Martinović, Anna (2013). Testing the L2MSS among Croatian university students: A pilot study. In Mihaljević Djigunović, Jelena, Marta Medved Krajnović, eds. UZRT 2012: Empirical Studies in English Applied Linguistics. Zagreb: FF Press, 183-192.

Martinović, Anna (2014). The Acquisition of English as a Second Language: Motivational Aspects (Unpublished doctoral dissertation). Zagreb: University of Zagreb.

Martinović, Anna (2017). L2 motivation and L2 anxiety among non-language university majors. In Cergol Kovačević Kristina, Sanda Lucija Udier, eds., Applied Linguistics Research and Methodology - Proceedings from the 2015 CALS Conference, Frankfurt am Main: Peter Lang, 121-134.

Martinović, Anna (2018). The L2 motivational self system: Differences among learners, Jezikoslovlje 19(1): 133-157.

Mihaljević Djigunović, Jelena (1998). Uloga afektivnih faktora u učenju drugoga jezika [Role of affective factors in FLL]. Zagreb: Filozofski fakultet Sveučilište u Zagrebu.

Mihaljević Djigunović, Jelena (2000). Uloga straha od jezika u učenju stranog jezika [The role of anxiety in learning a foreign language]. Strani Jezici 29(1-2): 9-13.

Mihaljević Djigunović, Jelena (2002). Strah od stranoga jezika - Kako Nastaje, kako se očituje i kako ga se osloboditi [Foreign Language Anxiety - How it emerges, How it is Revealed, How to Release it]. Zagreb: Naklada Ljevak.

Mihaljević Djigunović, Jelena (2004). Beyond language anxiety. SRAZ (Studia Romanica et Angelica Zagrabiensa) 49: 201-212.

Mihaljević Djigunović, Jelena (2006). Language anxiety and language processing. In Foster-Cohen, Susan H., Marta Medved Krajnović, Jelena Mihaljević Djigunović, eds. EUROSLA Yearbook 6. Amsterdam/Philadelphia: John Benjamins Publishing Company, 191-212.

Mihaljević Djigunović, Jelena, Vesna Bagarić (2007). A comparative study of attitudes and motivation of Croatian learners of English and German. SRAZ (Studia Romanica et Angelica Zagrabiensa) 52: 259-281.

Mihaljević Djigunović, Jelena, Vladimir Legac (2008). Foreign language anxiety and listening comprehension of monolingual and bilingual EFL learners. SRAZ (Studia Romanica et Angelica Zagrabiensa) 53: 327-347.

Noftle, Erik E., Richard W. Robins (2007). Personality predictors of academic outcomes: Big Five correlates of GPA and SAT scores. Journal of Personality and Social Psychology 93(1): 116-130.

O'Connor, Melissa C., Sampo V. Paunonen (2007). Big Five personality predictors of post-secondary academic performance. Personality and Individual Differences 43(5): 971-990. doi: 10.1016/j.paid.2007.03.017

Oxford, Rebecca (1999). Anxiety and the language learner: New insights. In Arnold, Jane, ed. Affect in Language Learning. Cambridge: Cambridge University Press, 58-67.

Oyserman, Daphna, Hazel R. Markus (1990). Possible selves and delinquency. Journal of Personality and Social Psychology 59(1): 112-125.

Oyserman, Daphna, Deborah Bybee, Kathy Terry, Tamera Hart-Johnson (2004). Possible selves as roadmaps. Journal of Research in Personality 38: 130-149. 
Oyserman, Daphna, Deborah Bybee, Kathy Terry (2006). Possible selves and academic outcomes: How and when possible selves impel action. Journal of Personality and Social Psychology 91(1): 188-204.

Pajares, Frank (2008). Motivational role of self-efficacy beliefs in self-regulated learning. In Schunk, Dale H., Barry J. Zimmerman, eds. Motivation and SelfRegulated Learning: Theory, Research, and Applications. New York, NY: Erlbaum, 111-139.

Papi, Mostafa (2010). The L2 motivational self system, L2 anxiety, and motivated behavior: A structural equation modelling approach. System 38(3): 467-479.

Pavičić Takač, Višnja, Nives Berka (2014). Motivation in foreign language learning: A look at type of school environment as a contextual variable. ExELL (Explorations in English Language and Linguistics) 2(2): 77-103.

Ryan, Stephan (2009). Self and identity in L2 motivation in Japan: The ideal L2 self and Japanese learners of English. In Dörnyei, Zoltán, Ema Ushioda, eds. Motivation, Language Identity and the L2 Self, Bristol: Multilingual Matters, 120143.

Salili, Farideh, Chi-yue Chiu, Ying-yi Hong (2001). The culture and context of learning. In Salili, Farideh, Chi-yue Chiu, Ying-yi Hong, eds. Student Motivation: The Culture and Context of Learning. New York: Kluwer Academic/Plenum Publishers, 1-14.

Schraw, Gregory, Stephen Lehman (2001). Situational interest: A review of the literature and directions for future research. Educational Psychology Review 13(1): 2352.

Schunk, Dale H., Paul R. Pintrich, Judith L. Meece (2010). Motivation in Education: Theory, Research, and Applications. Upper Saddle River, NJ: Pearson Education.

Taguchi, Tatsuya, Michael Magid, Mostafa Papi (2009). The L2 Motivational self system among Japanese, Chinese and Iranian learners of English: A comparative study. In Dörnyei, Zoltán, Ema Ushioda, eds. Motivation, Language Identity and the L2 Self. Bristol: Multilingual Matters, 66-97.

Tremblay, Paul F., Robert C. Gardner (1995). Expanding the motivation construct in language learning. Modern Language Journal 79(4): 505-520.

Weisberg, Yanna J., Collin G. DeYoung, Jacob B. Hirsh (2011). Gender differences in personality across the ten aspects of the Big Five. Frontiers in Psychology 2(178): 1-11. https://doi.org/10.3389/fpsyg.2011.00178

Williams, Marion, Robert L. Burden (1997). Psychology for Language Teachers. Cambridge: Cambridge University Press.

You, Chenjing, Zoltán Dörnyei (2014). Language learning motivation in China: Results of a large-scale stratified survey. Applied Linguistics 37(4): 495-519.

You, Chenjing, Zoltán Dörnyei, Kata Csizér (2016). Motivation, vision, and gender: A survey of learners of English in China. Language Learning 66(1): 94-123.

Young, Dolly J. (1992). Language anxiety from the foreign language specialist's perspective: Interviews with Krashen, Ommaggio-Hadley, Terrell, and Rardin. Foreign Language Annals 25: 157-172. 


\section{Authors' addresses:}

Anna Martinović

University of Zadar

Department of English

amartino@unizd.hr

Obala Kralja Petra Krešimira IV. Br. 2

23000 Zadar, Croatia

Izabela Sorić

University of Zadar

Department of Psychology

isoric@unizd.hr

Obala Kralja Petra Krešimira IV. Br. 2

23000 Zadar, Croatia

Received: May 92019

Accepted for publication: June 192019 